\title{
Participatory Learning Through Instructional Games for Functional Literacy Students of SKB Binjai
}

\author{
Silvia Mariah $\mathrm{H}^{1 *}$, Sani Susanti ${ }^{1}$, Albert Pauli Sirait ${ }^{1}$, Elvi Mailani ${ }^{1}$ \\ \{*zylvie@unimed.ac.id $\}$ \\ Universitas Negeri Medan, Medan, Indonesia
}

\begin{abstract}
The purpose of this study is to develop participatory learning through instructional games for functional literacy students of Sanggar Kegiatan Belajar (SKB) Binjai. In general, the students of functional literacy program are adults who have not had time to complete their education in formal education, so this research is carried out to help these adults learn, given that adults will only learn something that appropriate with their needs. Based on the preliminary research, it is found that the learning process recently uses a conventional approach where the curriculum, questions, discussions, and assessments are designed by the tutor according to the needs of the learners. Through this participatory learning, students are given the freedom to determine learning programs, design, and develop learning patterns as well as release their stress from daily routine through instructional games. Learning through instructional games is defined as the application of technology in the world of learning for an educational process. The media is a tool that can be used as a channel to achieve teaching objectives. If the media is designed properly and appropriately, it can be a fun learning with high interactivity element, and it can stimulate students to remember more about the material of learning. The most common obstacles encountered in nonformal learning are the lack of collaboration among the students' during the learning process and moreover tutor rarely gives a reflection on each meeting so that the shortcomings experienced by each student on each meeting cannot be determined and improved at the next meeting. Therefore, learning instructional games which consists of collaboration steps with tutor to plan, observe, and do reflection about the lessons. Based on the data analysis, the implementation of instructional games can increase learning activity. Increased learning activities will lead to the improvement of the quality of learning process and learning products. The application of these two aspects are proven can help students to identify the urgency of the problems occurred in the classroom, and seek for a solution in order to achieve more meaningful learning process. This result is corresponding with the concept of learning which is a process undertaken by a person to obtain changes in overall behavior that derived from the results of his/her own experience in interaction with the environment.
\end{abstract}

Keywords: Participatory Learning, Instructional Games, Functional Literacy Students.

\section{Introduction}

\subsection{Background}

The general purpose of national education is to create advanced, independent, and prosperous people and people of Indonesia both physically and spiritually. Human and 
developed society can be reflected in the increasingly high level of education, knowledge, skills, mental attitude, health, income, and future-oriented cultural values.

Along with the educational curriculum that continues to evolve, the learning process is not only focused on theory. Learning citizens need to be directed to be able to absorb the experience of the learning process that is designed interesting and fun. Therefore, learning in the classroom must be able to change the mindset and reduce learning citizens to learn, argue, take initiative, or interact.

In general, the process of learning functional literacy that takes place only focuses on the competencies that the tutor wants to develop. Thus, the results achieved can not represent the knowledge and skills desired by the learning community. Through innovative and fun learning activities, the classroom atmosphere will not become rigid and monotonous. The learning citizens were invited to discuss, interact, and dialogue so that they were able to construct the concepts and meanings of the knowledge they learned. Learning citizens must also be accustomed to differing opinions and arguing that they become intelligent and critical.

Information Technology development in recent years has developed quite rapidly, so that this development has changed the paradigm of the community in seeking and obtaining information to be no longer limited to newspaper information, electronic audio visuals, but also other information sources such as through the internet.

One area that has had a significant impact on the development of technology and information is the field of education. Basically, education is a process of communication and information from educators to students that contains educational information that has elements: (1) Educators as one source of information; (2) Media as a means of presenting ideas; (3) Ideas and educational material as well; (4) Students themselves. The development of technology and information development and its application in education is a growing discourse at this time. Integration of information technology into education one of them is in the form of instructional games.

Today's tutors must start using the internet as a learning resource. With learning like this, it is hoped that the knowledge of tutors and learning citizens will develop. In addition, tutors and learning residents will also be accustomed to operating computer equipment.

Functional literacy education is a non-formal education program with an emphasis on the mastery of knowledge, functional skills, as well as the development of the attitude and professional personality of learning citizens. Recognition of the existence and function of functional literacy education in the community, raises a big problem for the government and society so that in its implementation this program can provide a guarantee of quality education that is really good. However, the challenges faced by the implementation of education do not stop at the agreed policies, but the application of learning models that are appropriate to the needs of the learning community. Therefore, a research is needed to answer the learning model.

\subsection{Research Purpose}

The purpose of this study was to develop a participatory learning model based on instructional games for the functional literacy learning group of Binjai City SKB. The research implementation activities are divided into three main stages which consist of:

(1) Phase of preliminary studies, empirical studies and policy studies

(2) Stages of model development

(3) Pre-test and post-test evaluation phase. 


\section{Methodology}

\subsection{Concept of Playing}

According to [1], "various games (games) can be made intentionally (intentionally) with the intention that children improve certain abilities based on learning experience. Through playing activities, various jobs are realized. Playing is an activity chosen by the child because it is fun, not because it will get a prize or praise". "Computers become popular as a teaching medium because computers have feature that other teaching media do not have before the existence of a computer" [2]. The forms of using computer-based interactive multimedia models in learning can be in the form of drill, tutorial, simulation, and games [3]. Basically, one of the objectives of learning with interactive multimedia is to replace and / or complement and support the elements as much as possible, the objectives, materials, methods and tools of research that exist in the teaching and learning process in the conventional education system that we normally do.

\subsection{Instructional Games}

Instructional games are designed with challenging and fun game patterns. The whole game in principle has a basic component that is used as a reference to generate motivation by creating creative ideas to arrive at the end of the game.According to [4], instructional games are divided into three components, as follows:

\subsection{Introduction (Introduction)}

The aim is to set the stage of the game and ensure students will understand what to do. If the opening is less interesting, it will lose the learning objectives, because students may only concentrate on solving nonessential problems from the instructional games themselves. In the opening there is usually a title or title, goals, rules / rules, instructions for playing / direction for use, and game choices.

\subsection{Form of Instructional Games (body of instructional games)}

This section includes: scenarios, game levels, game players, rules of the game, challenges in achieving goals, curiosity, positive competition, meaningful relationships between players and learning, ability to fight opportunities, win or lose, game choices, paths or steps to be taken, changes, types of activities, interactions in play.

\subsection{Closing}

In closing the game that must be considered is: telling who the winner is by giving the best score, giving rewards in the form of objects such as money, food, or additional games for free, providing information especially with feedback for players in improving the game in individual appearance, and last closing.

In developing instructional games, one of the first steps needed is making a flowchart. According to [5], "the flowchart is to design the flow model of thinking about the contents of the program". In each workflow design or an information processing should be based on the communicative flowchart visualization. The aim is that the flow and path of the work process can be easily understood and passed and the user is followed thoroughly and meaningfully. Furthermore, [5] added that "flowcharts are important, flowcharts must be able to show the flow or course of learning". The following is a flowchart of instructional games. 


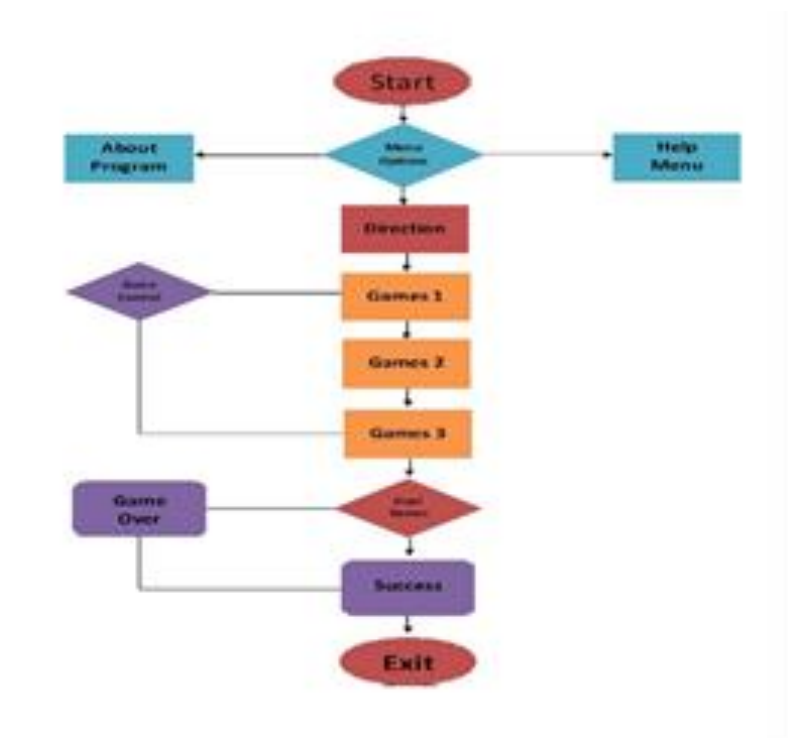

Fig. 1. Flowchart of Instructional Games [4]

From the observations carried out by researchers starting in January 2017, information was obtained that SMK Negeri 1 Panyabungan is a Business Management Vocational School. Initially this school took care of only the business and management fields of accounting expertise, office administration and marketing competence. Along with the progress of the times and the needs of the world of work in 2006, the Computer and Network Engineering $(T K J)$ expertise program was opened in the field of Information Technology and then developed again starting in 2016, the Multi Media and Banking expertise program was opened again. This school is one of the vocational schools that have implemented Production Unit $(U P)$. Management of UP in SMK Negeri 1 Panyabungan is carried out to enhance the potential of each study program in the form of services and goods consisting of the business fields of Stores, Mini Banks, Student Canteens, Typing Services, Photo Copy, Computer Screen Printing, Animation Design, Photographers, Computer, Warnet and Internet Network installation services.

Activities carried out at the UP marketing branch are management of student canteens and shops selling office equipment, electronic goods, basic needs of students, basic needs of the community and promotion of student services to the general public and other expertise programs. Branch UP accounting and banking activities have a mini bank services unit. Financial services managed are credit and debit services to customers for senior high school (SMA / SMK / MA) students in Mandailing Natal District. Where the mini bank works with 3 Commercial Banks, namely: North Sumatra Bank, Bank Rakyat Indonesia, and Bank Mandiri in the Panyabungan Branch. Activities at the Branch UP Office Administration are engaged in services in the type and photo copy in 3 (three) unit locations in Panyabungan. The location is placed in a strategic area, so that the services offered are very much visited by customers, both students, employees up to the general public. Branch UP TKJ and multimedia activities are computer service services, animation designers, computer screen printing and internet networks have 3 (three) units as well.

Many experts say about the understanding of the model according to the Indonesian Dictionary, model is defined as a pattern (example, reference, variety) of something that will 
be created or produced [2] Meanwhile, according to Martubi "The model is the abstraction of reality by focusing on several characteristics of real life [2]. Based on the opinions above it can be concluded that the model is a form of pattern that is emulated, either in physical form of a work or a picture (abtraction) of reality. Hasibuan said that: "Management is the science and art of managing the process of utilizing human resources and other resources effectively and efficiently to achieve a specific goal [3]. While Griffin suggested that management is the process of working together between individuals and groups and other resources in achieving organizational goals as activities of management [4]. From several definitions or understanding of management above, it can be summed up that management is: (a) the existence of cooperation between elements within an organization; (b) the existence of an effort to utilize the elements of the organization; (c) the existence of clear objectives to be achieved by the organization; (d) arrangements to achieve organizational goals.

According to Mulyasa the competence of expertise is a combination of knowledge, skills and attitudes that reflect in the habit of thinking and acting [5]. Further According to Boyatzis argues that the competence of expertise is the capacity that exists in someone who can make the person able to fulfill what is indicated by work in an organization capable of achieving the expected results [6]. From the definition of the statement above it can be concluded that the competence of expertise is defined as a set of mastery of skills, values and attitudes that must be possessed and mastered by students according to standards set by the government sourced from education, training and experience so that they can work professionally. From the description of the competency management management model development above, a conclusion can be drawn that the purpose of the competency-based management model development expertise in this study is an effort to utilize existing resources through planning, organizing, mobilizing and controlling to achieve the knowledge, skills and attitudes possessed students according to the graduates' competency standards ( $S K L) S M K$.

Vocational secondary education is the only one from the education system in schools that is specifically prepared to produce mid-level skilled labor to fill the needs of business, industry and development. In order to achieve the objectives of the defined production unit, schools in running this business unit must always carry out good management. Therefore, in implementing the production unit program, the school makes a management model, which is a business that produces goods or services, optimally utilizing all forms of capital in schools and management which are supported by a chain or business network that requires each other or mutually beneficial. In addition, businesses in the form of production units need to be supported by the management system such as: marketing, promotion, research and development, quality control, and others. Based on the link and match concept that has been mentioned that one of the realization is the production unit management policy at the school. The production unit can be said to be a miniature of a company that has a lot to do with everything related to the company, namely: business status, goals, objectives, scope and management in the business. Furthermore, business fields can be classified into production and services. The service sector is a business that can be directly enjoyed by consumers, while businesses in the field of production generally cannot be directly enjoyed by consumers.

This type is a type of experimental research that aims to find out the usefulness of instructional games used in the learning community. In this experimental study will be seen the effect of certain treatments on one group on another group under controlled conditions. This study involved two classes that were chosen randomly, namely the experimental class and the control class which were given different treatments. With the experimental class and control class, the results obtained from the treatment in the experimental class can be known because it is compared to the control class that is not treated. In the experimental class, the 
learning was given treatment with instructional games while the control class was not given treatment.

The type of experimental research used in this study is True Experimental Design, with the form of Posttest-Only Control Group Design, where in this design there are 2 groups selected randomly (R). the first group was treated (X) and the other group did not, the group treated was called the experimental group and the group not treated was called the control group. The effect of treatment (treatment) is $(\mathrm{O} 1: \mathrm{O} 2)$.

\section{Result and Discussion}

\subsection{Data Colection}

After the data collection is complete, the next step is to present the value data from observations or research. From the research conducted, the data obtained from the experimental class and the control class were obtained. The average of the initial and final observation indicators of the Control Class and Experimental classes are:

Table 1. Initial and Final Observation

\begin{tabular}{lccccc}
\hline \multirow{2}{*}{ No. } & \multirow{2}{*}{ Indicator } & \multicolumn{2}{c}{ Control Class } & \multicolumn{2}{c}{ Experiment Class } \\
\cline { 3 - 6 } & & Pre & Post & Pre & Post \\
\hline 1 & Descriptor 1 & 13,37 & 14,68 & 13,31 & 20,93 \\
2 & Descriptor 2 & 12,25 & 13,5 & 12,93 & 20,62 \\
3 & Descriptor 3 & 12,68 & 13,43 & 12,93 & 21,06 \\
4 & Descriptor 4 & 13,43 & 14,18 & 13,87 & 20,87 \\
5 & Descriptor 5 & 12,37 & 12,81 & 12,93 & 21 \\
\hline
\end{tabular}

\subsection{Preliminary Observations of Experiments Class and Control Class}

Initial observation or pretest is done in the first week, which is without being given treatment to determine the ability of each class both experimental and control classes. In summary, the results of the initial observations of the two groups are shown in the table.

Table2. Early Observation Data for Experiment Class and Control Class

\begin{tabular}{cccc}
\hline No & Statistics & Experiments Class & Control Class \\
\hline 1 & Number of students $(\mathrm{n})$ & 16 & 16 \\
2 & Total Grade $\left(\sum \mathrm{Xi}\right)$ & 42,24 & 41,2 \\
3 & Mean $(\bar{X})$ & 2,64 & 2,57 \\
4 & Standard Deviation $(\mathrm{SD})$ & 0,146 & 0,141 \\
5 & Variance $\left(\mathrm{S}^{2)}\right.$ & 0,021 & 0,020 \\
\hline
\end{tabular}

\subsection{Final Observations of Experimental Classes and Control Classes}

After the initial ability was discovered through initial observation, a group was formed for the experimental class and the control group. For the experimental class, class B applied learning with media instructional games, while in the control class A used conventional learning or without media. At the end of the meeting, the learning residents were given a final observation (post-tet), to find out the development of the ability to master the material of the two class learning citizens after learning with instructional games in the experimental class and conventional learning in the control class. Feel the result of posttest, it can be seen that the 
ability of learning people in the experimental class has increased while in the control class does not experience an increase or tend to be static, where the average value of the learning population in the experimental class is 4.19 and the average value of the control class is 2.745 . In summary, the results of the initial observations of the two groups are shown in the following table.

Table3. Final Observation Data for the Experiment Class and Control Class

\begin{tabular}{clcc}
\hline No & \multicolumn{1}{c}{ Statistics } & Experiment Class & Control Class \\
\hline 1 & Number of students $(\mathrm{n})$ & 16 & 16 \\
2 & Total Grade $\left(\sum \mathrm{Xi}\right)$ & 67,04 & 43,92 \\
3 & Mean $(\bar{X})$ & 4,19 & 2,745 \\
4 & Standard Deviation $(\mathrm{SD})$ & 0,248 & 0,189 \\
5 & Variance $\left(\mathrm{S}^{2)}\right.$ & 0,053 & 0,03 \\
\hline
\end{tabular}

From the results of the calculation of the initial and final observations above, it can be seen the difference between the average of the initial and final observations of the experimental class and the control class. In summary, the average value of the citizens of the two classes learning from initial to final observation can be seen in the following table.

Table 4. Summary of Average Initial and End Observation Values for Experiment and Control Class

\begin{tabular}{lllll}
\hline \multirow{2}{*}{ Statistics } & \multicolumn{2}{c}{ Experiment Class } & \multicolumn{2}{c}{ Control Class } \\
\cline { 2 - 5 } & Pre & Post & Pre & Post \\
\hline Total Grade $\left(\sum \mathrm{Xi}\right)$ & 42,24 & 67,04 & 41,2 & 43,92 \\
Mean $(\bar{X})$ & 2,64 & 4,19 & 2,57 & 2,745 \\
\hline
\end{tabular}

Descriptively, mastering the material on the initial and final observations in the experimental class and control class can be explained as follows:

a. The average initial observation of the experimental class (2.64) is higher than the average initial observation of the control class (2.57). Experiment Class> Control Class $=2.64>2.57$.

b. The average final observation of the experimental class (4.19) is higher than the control class average (2.745). Experiment Class $>$ Control Class $=4,19>2,745$.

c. The average difference between the initial observation between the experimental class and the control class is 0.07 and the difference between the final average between the experimental class and the control class is 1.445 .

\subsection{Hypothesis Testing}

Table 5. Summary of Calculation of Hypothesis Testing

\begin{tabular}{cccccc}
\hline No & Data & Mean & $\mathbf{T}_{\text {count }}$ & table & Conclusion \\
\hline 1 & Experiment Class & 4,19 & \multirow{2}{*}{20,64} & \multirow{2}{*}{1,708} & Significant \\
2 & Control Class & 2,745 & & & \\
\hline
\end{tabular}

From the table, it can be seen that the average mastery ability of the material using instructional games using media is higher than the average class with conventional learning. Based on the results of these calculations, it is obtained the results of the t test of 20.64 , the 
value of thutung is greater than the value of $t$ table (20.64> 1.462). Thus, learning using instructional games influences the mastery of the material.

Based on the results of data analysis, it can be concluded that instructional games affect the mastery of learning material. This can be seen from the data obtained before and after buying the instructional games in the experimental class and the control class without instructional games. Before giving different treatments to the two sample classes, the researcher first made an initial observation to see the initial ability in both sample classes.

In the initial observations in the experimental class and control class, the ability of citizens to learn is not good. This is because in the media training given or used by tutors, the variety varies. After the treatment is given to the experimental class, the researcher conducts a re-assessment (post-test) using the same instrument as the initial assessment instrument (pretest). The same is true for the control class, which is to reassess it using the same instrument as the assessment instrument in the experimental class without treatment.

At the time of the initial observation, achieving the score of the learning ability of the students in the experimental class was 2.64 and in the class of 2.57, the initial ability score in the experimental class and control class was almost the same. Then tested the differences in initial linguistic intelligence scores and obtained Fcount $<$ Ftable or $1.05<2.43$ then concluded that both samples had homogeneous variance.

After different treatments were carried out namely the experimental class using instructional games and in the control class without instructional games, the scores in the experimental class were 2.64 and in the control class 2.57 . From the results of the final observations of the two samples, a difference of 0.07 was obtained. From the data obtained there are significant differences between the mastery of the material in the experimental class and the control class. In the experimental class the mastery of matter has increased in terms of reading, writing and counting. While the control class does not experience an increase or tends to be static. This is because the learning by using instructional games media feels interesting and fun, so that the residents learn to enjoy learning, and the mastery of the material also increases.

Based on the explanation above, one of the media that can be used and influences the ability of learning citizens is through instructional games. Through instructional games that are adapted to the theme of learning and in accordance with the needs and development of learning citizens, a concept will be easier to instill through direct activities with the media. Tutors or educators need to have special skills and abilities both in planning, implementing, and evaluating ongoing learning activities by paying attention tothe development of each learning citizen.

\section{Conclusion}

Based on the discussion of the results of the research that has been carried out, it can be concluded that the instructional games media can affect the learning abilities of learning citizens. Ability improvement can be seen in the final observation, where the average value of the experimental class linguistic intelligence using instructional games is higher than the control class without the use of instructional games or conventional learning. Tutors have also played an active role in using instructional games not only to direct, but have mastered the application. 
Learning by using instructional games provides a good influence on learning citizens rather than conventional learning. This is in accordance with the hypothesis test obtained by $\mathrm{t}$ count> $\mathrm{t}$ table, which is 20.64> 1.462. So that it can be said that HO is rejected and Ha is accepted, then the use of instructional games media influences the ability to read, write, and count learning citizens.

\section{Suggestion}

Based on the discussion and conclusions stated above, the researchers suggest the following:

(1) For tutors and prospective teachers, they are expected to be able and skilled in designing active and innovative learning that can be done to improve the ability of learning citizens.

(2) Program institutions can provide tutors the opportunity to attend seminars related to improving the learning process in an effort to improve the learning process.

(3) For the next researcher, it can be an input in conducting further research on the application of instructional games in learning.

(4) For readers can add knowledge.

\section{References}

[1] C. R. Semiawan, Landasan Pembelajaran dalam Perkembangan Manusia. Jakarta: Centre of Human Competency Development, 2007.

[2] Munir, Konsep dan Aplikasi Program Pembelajaran Berbasis Komputer (Computer Based Interaction). Bandung: P3MP UPI, 2005.

[3] Rusman, Model-model Multimedia Interaktif Berbasis Komputer. Bandung: P3MP UPI, 2005.

[4] Rusman, Belajar dan Pembelajaran Berbasis Komputer. Bandung: Alfabeta, 2012.

[5] D. Darmawan, Teknologi Pembelajaran. Bandung: Rosda, 2013. 